() Entomologica Fennica. 12.X.1993

\title{
The distribution of Odonata in Västerbotten and South Lapland, northern Sweden
}

\author{
Frank Johansson
}

\begin{abstract}
Johansson, F. 1993: The distribution of Odonata in Västerbotten and South Lapland, northern Sweden. - Entomol. Fennica 4:165-168.

Distribution maps for odonate species from the faunistic Swedish provinces Västerbotten, Åsele Lappmark and Lycksele Lappmark are presented. The maps are based on 176 localities sampled between 1986-1992. Twenty-four species were found in the area, and 10 of these are classified as common, while two are very rare.
\end{abstract}

Frank Johansson, Department of Animal Ecology, University of Umeå, S90187, Umeå, Sweden

\section{Introduction}

Knowledge of the distribution of a species may help us to understand why a species is confined to its present range. When did the distribution of a species expand or contract and what were the reasons? What roles do abiotic and biotic factors play in setting the distribution limits? And so on. It follows that sound knowledge regarding the distribution of species is of prime importance. Further, since the impact of mankind upon the environment is increasing dramatically, it is important to have the background data necessary for measuring such impact.

Recently, several books including distribution maps dealing with the odonates of Europe have been published (d'Aguilar et al. 1986, Sandhall 1987, Askew 1988). Unfortunately these maps do not give a valid picture of distributions within the boreal zone of northern Europe. This shortcoming is an artefact due to the limited collecting of odonates in these areas. Most of the cited data are old and tell us little about recent distributions. Data from northern Sweden are also available from the middle years of this century, as presented by Ander (1931, 1944, 1946, 1950, 1951, 1953), and Valle (1952), as well as some more recently published data (Jensen \& Mend1 1974, Johansson 1988, 1991, 1992, Mendl 1981, Norling 1984, Sahlén 1985, 1987). Most records cited by Ander $\&$ Valle are old (some dating back more than 100 years), while others represent provincial records only. The more recent publications listed are mostly restricted in area or give only provincial records. To improve the situation I here present my records from 7 years of sampling (19861992) within the faunistic provinces Västerbotten, Åsele Lappmark and Lycksele Lappmark (Fig. 1).

\section{Study area and methods}

The region studied covers a transect from the Bothnian coast in the east to the western mountains. Along this transect there is considerable change in climate, temperatures decreasing from east to west (Liljequist 1970). Altogether 176 localities have been sampled, i.e. either nymphs, adults or both have been collected. The number of localities sampled is highest in the coastal areas (Fig. 2). Consequently, many species may be more common in the western parts than shown 


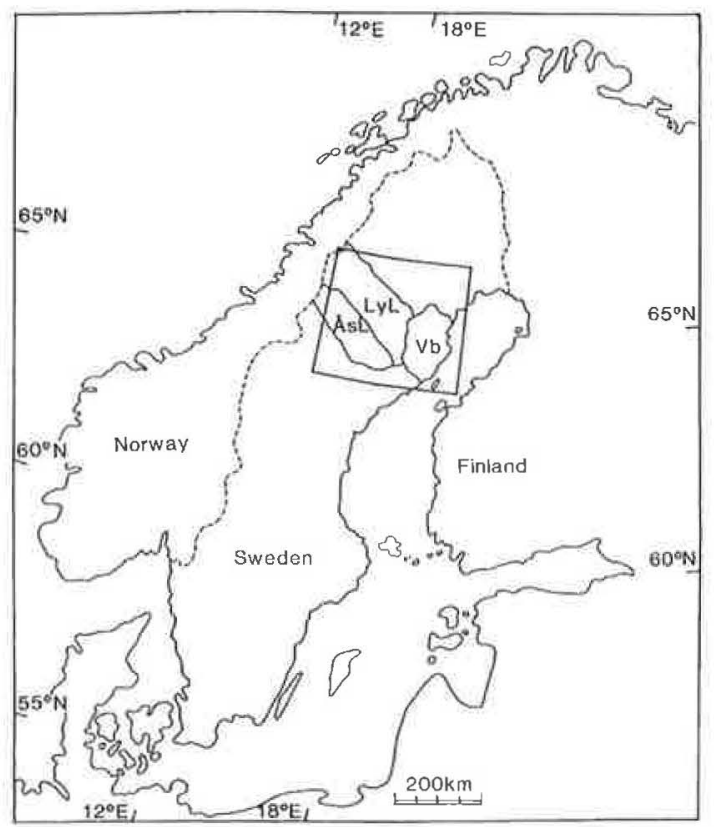

Fig. 1. Map showing the investigated area and the three faunistic provinces considered for odonate distribution.

on the maps. The presence of a species is marked by a dot according to the Universal Transversal Mercator (UTM), (Fig. 2). I define the mountain zone as the area above the upper coniferous limit. This zone consists of birch forest and above this an alpine region. Below, I comment on the distribution of the species recorded. Together with the distribution maps (Fig. 3) I also give the most common habitat(s) for each species. The taxonomy and nomenclature are according to Sandhall (1987).

\section{Species account}

Of the 24 species found, ten are common in the whole area outside the highest mountains: Calopteryx virgo, Enallagma cyathigerum, Coenagrion hastulatum, $C$. johanssoni, Aeshna juncea, $A$. caerulea, Cordulia aenea, Somatochlora metallica, Leucorrhinia dubia, L. rubicunda. Of these ten species some are fairly common in the mountain area as well: A. juncea, A. caerulea, L. dubia and $L$. rubicunda, with $A$. caerulea being more

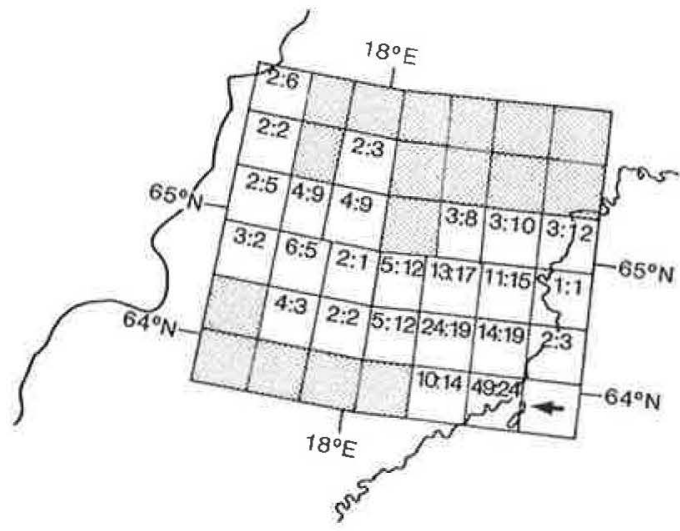

Fig. 2. Map showing the international UTM grid system of the area considered for odonate distribution (squares measure about $50 \times 50 \mathrm{~km}$ ). Figures in squares are number of localities investigated and number of species recorded respectively in each square. Hatched squares were not investigated.

abundant in the central and western area compared to the coastal region. The five species $C$. hastulatum, A. juncea, C. aenea, L. dubia and $L$. rubicunda are found abundantly at almost every locality sampled, and consequently they may be judged as very common outside the mountains.

The following species are common in the coastal area but appreciably rarer further inland: Lestes sponsa, Coenagrion lunulatum, C. armatum, Erythromma najas, Aeshna grandis, Cordulegaster boltoni, Cordulia aenea, Libellula quadrimaculata and Sympetrum danae. Of these C. armatum, A. grandis, C. aenea and L. quadrimaculata reach farthest to the west. $L$. sponsa and $S$. danae are probably more or less restricted to the coastal area. Here they can be locally very abundant. These two species have an obligate one year life cycle (Sandhall 1987, Askew 1988) and should benefit from the long late summer period in this area.

Of the species judged as not being common, Aeshna subarctica is probably present in the whole area, though not common. This species is very similar to A. juncea (e.g. d'Aguilar et al. 1986), and it is easily overlooked. Somatochlora alpestris and S. arctica are probably also present in the whole area, since they are species known to occur the farthest to the north and at the highest elevations in the Swedish mountains (Ander 
NTOMOL. FENNICA Vol. 4 - Johansson: Odonata in northern Sweden

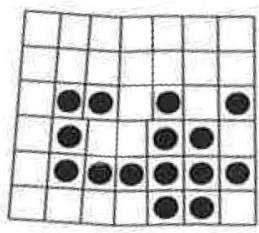

Caloplery $\times$ virgo (Linné)

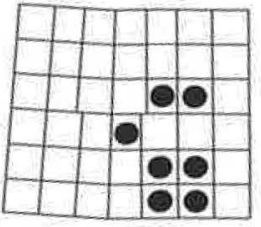

Coenagrion armalum (Charpentier)
MP ML

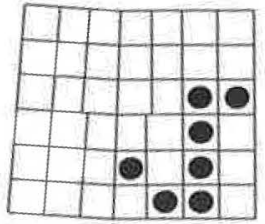

Erylhromma najas (Hansemann)

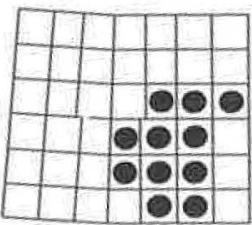

Aeshna grandis (Linné)

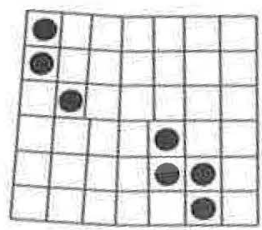

Somalochlora alpestris (Sélys)
$B P$

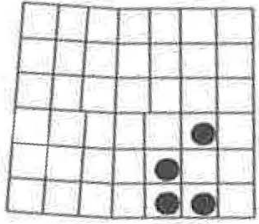

Sympelrum danae (Sulzer)

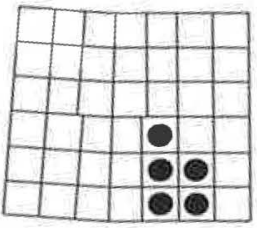

Pyrrhosorna nymphula (Sulzer)
SS

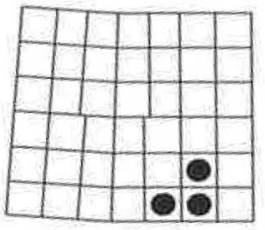

(unulatum (Charpentier)

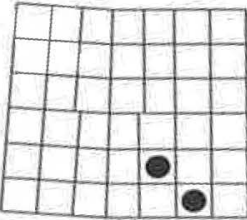

Aeshna subarclica Walker

$$
\begin{array}{r}
\text { Aeshna juncea (Linné) } \\
\text { BP MP ML. }
\end{array}
$$

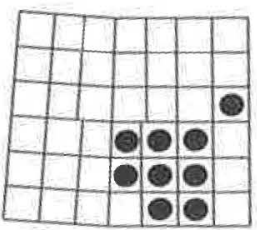

Cordulegaster bolloni (Donvan)

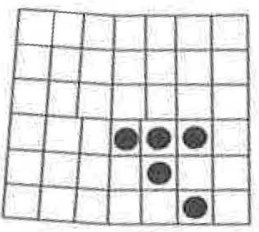

Somatochlora arctica (Zeilersiedt)

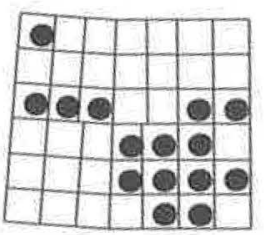

Leucorrhinia dubia (Van der Linden)
BP MP ML

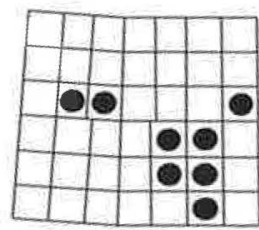

Enallagma cyathigerum (Gharpenlier)
MP BP ML

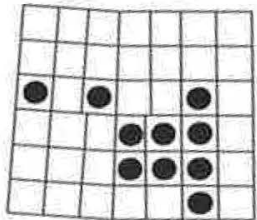

Coenagrion johanssoni (Wallengren)
BP

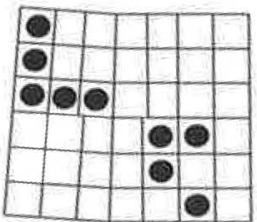

Aeshna caerulea (Ström)

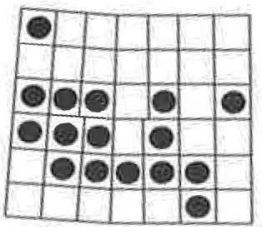

Somalochlora metallica (Van der Linden)

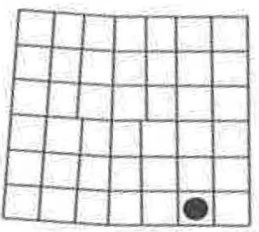

Sympetrum vulgatum (Linné)

Leucorrhinia albiirons (Burmeister)
BP

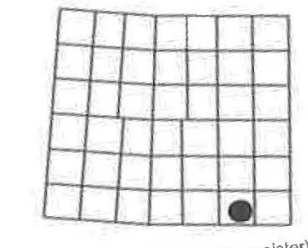

habitats of Odonata in Västerbotten. Habitat abbreviations: BP bog ponds; MP

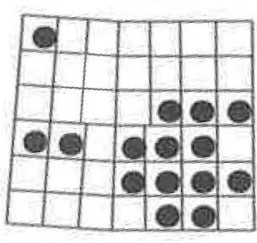
Leucorrhinia rubicunda (Linné)
BP MP ML.

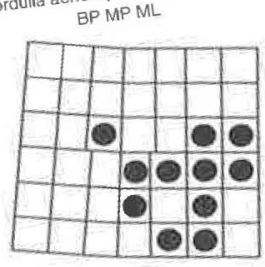

Libellula quadrimaculala Linné
ML MP BP Fig. 3. Distribution and commotrophic lakes; $M$
mesotrophic ponds; OL oligotroph 
1951). Pyrrhosoma nymphula is found in 5 localities only, but is fairly abundant in these. Sympetrum vulgatum and Leucorrhinia albifrons are the only species considered to be rare. They are found at one locality each. However, as several individuals were observed, and the species have been found during two consecutive years, I do not regard these as occasional records.

Acknowledgements. Thanks to Anders Nilsson and Christian Otto for valuable comments on the manuscript. Ulf Norling verified several identifications and Görel Marklund drew the figures. Finally I would also like to thank all those who have supplied me with collections of odonates for this publication.

\section{References}

d'Aguilar, J., Dommanget, J-L. \& Préchac, R. 1986: A guide to the dragonflies of Britain, Europe and North Africa, translated by Brooks, S., Brooks, N. \& Robertson, T.S. - Collins, London. 336 pp.

Ander, K. 1931: Bidrag till kännedom om de svenska Odonaterna 5, Norrländska trollsländor. - Entomol. Tidskrift 52:228-244.

- 1944: Catalogus Insectorum Sueciae, IV, Odonata. Opuscula Entomol. 9:157-163.

- 1946: De svenska odonaternas djurgeografi. Bidrag till kännedom om de svenska odonaterna 6. - Opuscula Entomol. 11:109-118.

_ 1950: Zur verbreitung und Phänologie der Boreoalpinen Odonaten der Westpaläarktis. — Opuscula Entomol. 15:53-71.
- 1951: Odonata. - In: Brinck, P. \& Wignstrand, K. G. (eds.): The mountain fauna of the Virihuare area in Swedish Lappland. II. Kungl. Fysiogr. Sällsk. Handl., N.F. Avd. 2 46(2):123-126. Lund.

- 1953: Catalogus Insectorum Sueciae; Odonata additamenta. — Opuscula Entomol. 18:87-88.

Askew, R. R. 1988: The dragonflies of Europe. - Harley Books, Essex. 291 pp.

Jensen, C. F. \& Mendl, H. 1974: Trollsländor (Odonata) i Kaltisjokko området. — Norrbottens Natur 30:17.

Johansson, F. 1988: Förbiseddda trollsländor (Odonata) i Norrland. - Natur i Norr 7:36-37.

- 1991: Trollsländor från Holmöarna. - Natur i Norr 10:70-71.

- 1992: Nya landskapsfynd av trollsländor (Odonata) mellersta Norrland. — Entomol. Tidskrift 113:56-57.

Liljequist, G. H. 1970: Klimatologi. - Generalstabens Litografiska anstalt, Stockholm. 527 pp.

Mendl, H. 1981: Dragonflies (Ins Odonata) in the estuarity of the river Ängerån. — Fauna Norrlandica 1:1-7.

Norling, U. 1984: The life cycle and larval photoperiodic responses of Coenagrion hastulatum (Charpentier) in two climatically different areas (Zygoptera: Coenagrionidae). - Odonatologica 13:429-449.

Sahlén, G. 1985: Trollsländor i Medelpad. — Entomol. Tidskrift 106:155-156.

- 1987: Landskapsförteckning över norra Sveriges trollsländor. - Natur i Norr 1:35-38

Sandhall, §. 1987: Trollsländer i Europa. - Interpublishing, Stockholm.

Valle, K. J. 1952: Die Verbreitungsverhältnisse der ostfennoskandischen Odonaten. - Acta Entomol. Fennica 10:1-87.

Received 10.XI.1992 